\title{
Casino Teatrets rollehefter
}

af cand.mag. \& phil. Martin Dyrbye

I 1941 besluttede generalkonsul Hans Carlsen og fru Linden, enke efter Casino's sidste direktør, at skænke sufflørbøger, rollebøger, musikalier, billeder og programmer til Det kongelige Bibliotek. I brev af 19. april 1941 anførte Ernst Carlsen, på givernes vegne, at „Overdragelsen sker paa Betingelse af, at Arkivet skal bære Navnet CASINO ARKIVET og aldrig maa splittes", foruden angivelsen af givernes navne. Ifølge givernes ønske skulle arkivet være tilgængeligt, „,eventuelt ogsaa for Udlaan til Interesserede."

På foranledning af Teatermuseet henstillede giverne, at „,saafremt der ikke derved sker en Svækkelse af CASINO ARKIVET's Værdi, at Teatermuseet overlades en Del af den Arkivet tilhørende Fotografisamling samt Program- og Regis-Bøger."

Endelig bad giverne Det kongelige Bibliotek drage omsorg for, at arkivet, „, af Hensyn til Udløbet af Lejemaalet“ blev afhentet fra Sct. Andreas Kollegiet, som var blevet benyttet som opbevaringssted.

Gennem dr. phil. Torben Krogh, som ifølge et brev dateret den 18. april 1941 havde udlånt overbibliotekaren „tre Registranter over Casinos Arkiv", fik overbibliotekaren lejlighed til at orientere sig om arkivets bestående dele og blev derved klar over, hvilke skatte arkivet i hovedtræk kunne tænkes at rumme. Naturligvis måtte arkivet hurtigst muligt bringes „i hus". Formentlig havde Torben Krogh gennem Ernst Carlsen hørt, at man overvejede en overdragelse af arkivet til Det kongelige Bibliotek, og udlånet af registranterne skal ses på denne baggrund.

Samme dag som gavebrevet blev modtaget, svarede overbibliotekar Carl S. Petersen på Det kongelige Biblioteks vegne, at man med 
"levende Erkendtlighed" havde modtaget givernes brev. Gaven ville, anførte overbibliotekaren, supplere bibliotekets „i Forvejen betydelige Samlingertilbelysning afdansk Aands-og Kulturlivi videsteUdstrækning" og måtte betragtes som "en i høj Grad værdifuld Forøgelse", hvorfor biblioteket måtte bringe "dets hjertelige og uskrømtede Tak."

Fra modtagers side ønskede man ligeledes at respektere givernes ønsker og snarest hente arkivet, hvilket skete allerede mandag den 21. april 1941. Samme dag orienterede overbibliotekaren Teatermuseets leder, Robert Neiiendam om den stedfundne aflevering og givernes bestemmelser omkring gaven vedrørende udskillelsen af dele med henblik på museet. Overbibliotekaren fortsatte: „Jeg kan ikke tænke mig, at der skulle opstaa Vanskeligheder mellem Dem og mig i denne Sag, og saa snart jeg faar Arkivet i Hus og opstillet, skal jeg sætte mig i Forbindelse med Dem, for at vi i Fælleskab kan se paa Tingene."

Efter at Casinos Arkiv var blevet modtaget af biblioteket „, i god Behold", kunne Carl S. Petersen overfor giverne bekræfte modtagelsen, samt takke for de førnævnte "tre haandskrevene Fortegnelser over Arkivet", som man et par dage efter overdragelsen „erholdt" fra generalkonsul Ernst Carlsen.

Derpå ville overbibliotekaren atter sætte sig i forbindelse med Teatermuseet. Fra museets side takkede Robert Neiiendam for Carl S. Petersens "Tilkendegivelse", som han kendte til gennem generalkonsulen, og nu afventede museet "altsaa at høre nærmere".

Den betydelige gave vakte i samtiden opmærksomhed i aviserne. I Politiken den 21. april heftede man sig ved, at samlingen ikke blev overdraget til "det for nogle Aar siden oprettede Dramatiske Bibliotek" beliggende på Universitetsbiblioteket, således som det ellers var tilfældet, da Dagmar-Teatrets arkiv blev afleveret. Det ville, mente bladet, „sikkert undre mange, at de store Privatteaterarkiver nu splittes ad og ikke samles paa et sted."

Til kritikken svarede Carl S. Petersen, at der ikke var „Tale om nogen Splittelse", og fortsatte:

"-Det kgl. Bibliotek ejer jo i Forvejen en stor Del af vort største Teaterarkiv, Det kgl. Teaters, og desuden har vi Landets største Musiksamling. Saa efter min Mening passer Casinos Arkiv bedst paa Det kgl. Bibliotek. Vi er meget glade for den værdifulde Gave. Den vil komme til at figurere som en særskilt Samling: Casino-Arkivet. Jeg har endnu ikke haft Lejlighed til at gaa det igennem, men der er jo ingen Tvivl om, at det indeholder mange 
interessante Ting og giver et ret enestående Billede af Teaterkulturliv gennem næsten et Aarhundrede."

Overbibliotekaren fandt navnlig sufflørbøgerne interessante, og da mange af teatrets stykker aldrig var blevet trykt, kunne i det mindste forfatternes tekster rekonstrueres, og i et længere interview i Berlingske Tidende den 13. maj bemærkede han, at der i arkivet måtte ligge „mange udmærkede og nye Ting, vigtige Bidrag til studiet af den københavnske Kultur."

En anden vigtig grund til at modtage gaven „med særlig aabne Arme" - hvortil avisens udsendte i parentes bemærkede: „faa Mennesker kan aabne Armene saa indbydende som Det kongelige Biblioteks joviale og vennesæle Overbibliotekar" - var ifølge Carl S. Petersen, at "CasinoRepertoiret rummer en Masse Musikalier, ikke blot fra de store Oprette-aar, da Offenbach med følge erobrede København, men ogsaa Visemusik fra Erik Bøgh-Perioden og andet lignende. Det hele kommer nu til at fylde sin Plads i vor Samling af Musikalier, der i Forvejen er den største danske Musikaliesamling, og det er jo rart at se Tingene samles, at se Stoffet kompletteres. Vi ejer saa godt som alle vigtige danske Kompositioner i Originalmanuskripter."

Om gavebrevets bestemmelser vedrørende overdragelseaf enkelte dele fra arkivet til Teatermuseet, af Berlingske omtalt som „,rare Dryp “, blev det i samme artikel understreget, at kun materiale, som kunne undværes, blev overdraget og den „smilende" Carl S. Petersen sluttede: „Og saa glæder vi os til at gaa i gang med det rige Arkiv, saa det snarest muligt kan blive tilgængeligt for Forskere."

Iefteråret 1941, den 14. september 1941, rykkedeRobert Neiiendam Det kongelige Bibliotek for „de Billeder fra Casino-Forestillingerne, som skulde overgaa til Teatermuseet". Derfra havde man modtaget en henvendelse fra givers side, om hvorvidt sagen var i orden, "men det er den jo ikke“, anførte Robert Neiiendam utålmodigt, og fortsatte: „Jeg kommer gerne efter Tilsigelse en Dag over paa Biblioteket og udvælger, hvad der måtte være af Interesse for Samlingen her." I et privat p.s. viste Robert Neiiendam dog sin store velvilje overfor Carl S. Petersen, da han orienterede denne om en fælles bekendt, der nyligt var blevet interneret for anden gang i Møllegadens Kaserne, og som havde det rædsomt.

Dagen efter, den 15. september, modtog Robert Neiiendam overbibliotekarens velvillige svar - han havde "ingenlunde glemt" sine „Forpligtelser" i henseende til "Casino-Sagerne“, men svarede han: „...dels 


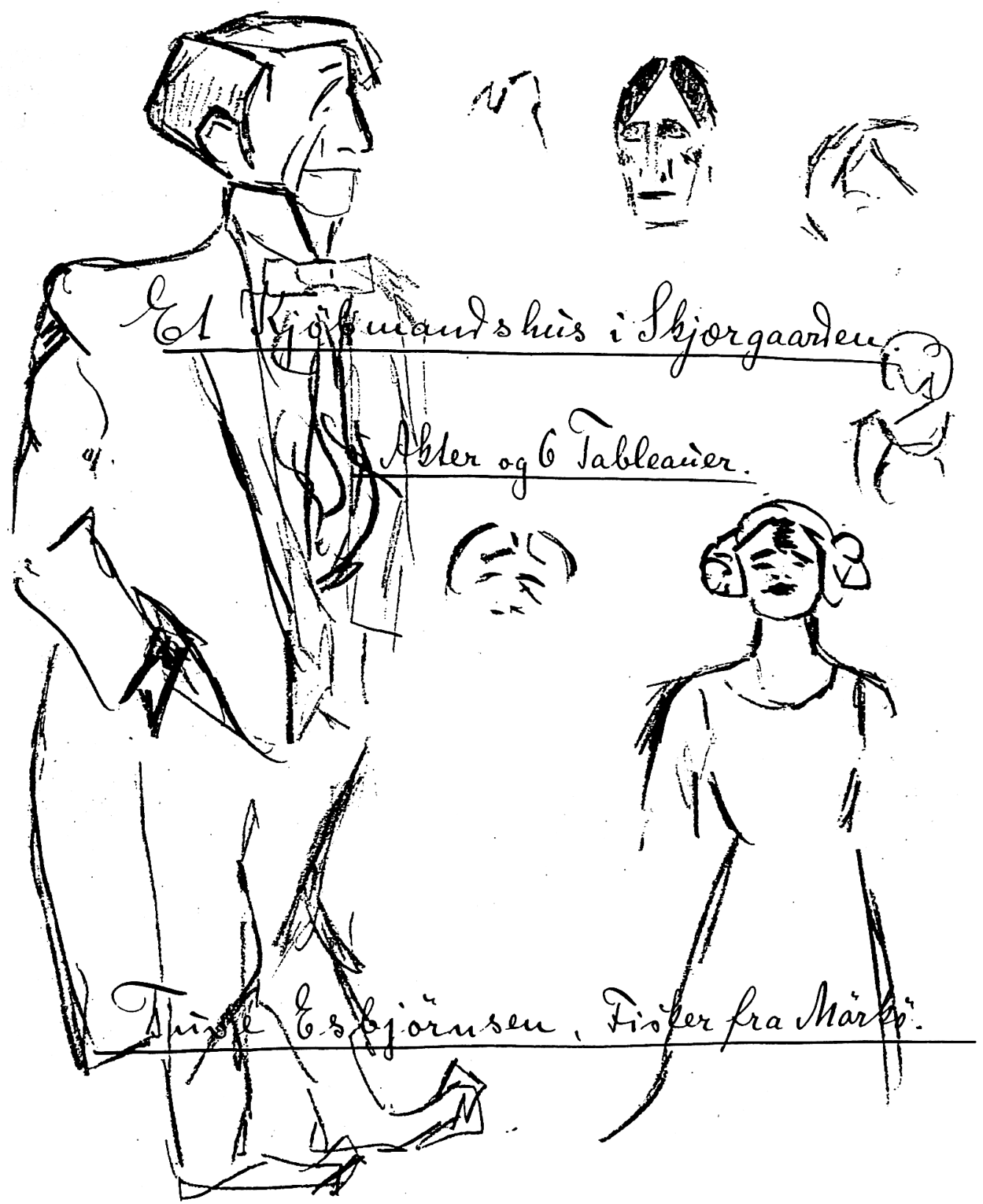


llustrationer fra "Et KjøbmandshusiSkærgaarden. Folkekomedie med Sange og Kor i 5 Akter og 6 Tableauer" efter Emielie Carléns roman og bearbejdet af P. Fristrup med musik arrangeret efter svenske folkeviser. Den populære folkekomedie opførtes henholdsvis fra 5 . oktober til 25 . november 1890, ialt 42 gange, og kom atter på plakaten den 14. februar 1911 og blev spillet for sidste gang den 27 maj ved sæsonens slutning, ialt 36 gange. Under begge opførelser medvirkede nogle af samtidens mest populære og afholdte skuespilllere og skuespillerinder.

For hovedparten af de medvirkendes vedkommende kan deres navne forbindes til de enkelte roller, da skuespillernes navneer anførte på rollehefternes omslagsblad og med tydelig angivelse af årstal. I rollehefterne findes desuden oplysninger om strygninger, rettelser m.v.

Rollen som "Tuve Esbjørnsen, Fisker fra Malmø" udførtes i 1890 af Hr. Larsen, medens den i 1911 blev giet af Hr. Blumensaadt. I deres rollehefte findes tegninger af fiskeren og enkelte af de øvrige medvirkende, men det lader sig imidlertid ikke fastslå, hvem af d'herrer, som stod bag tegningerne.

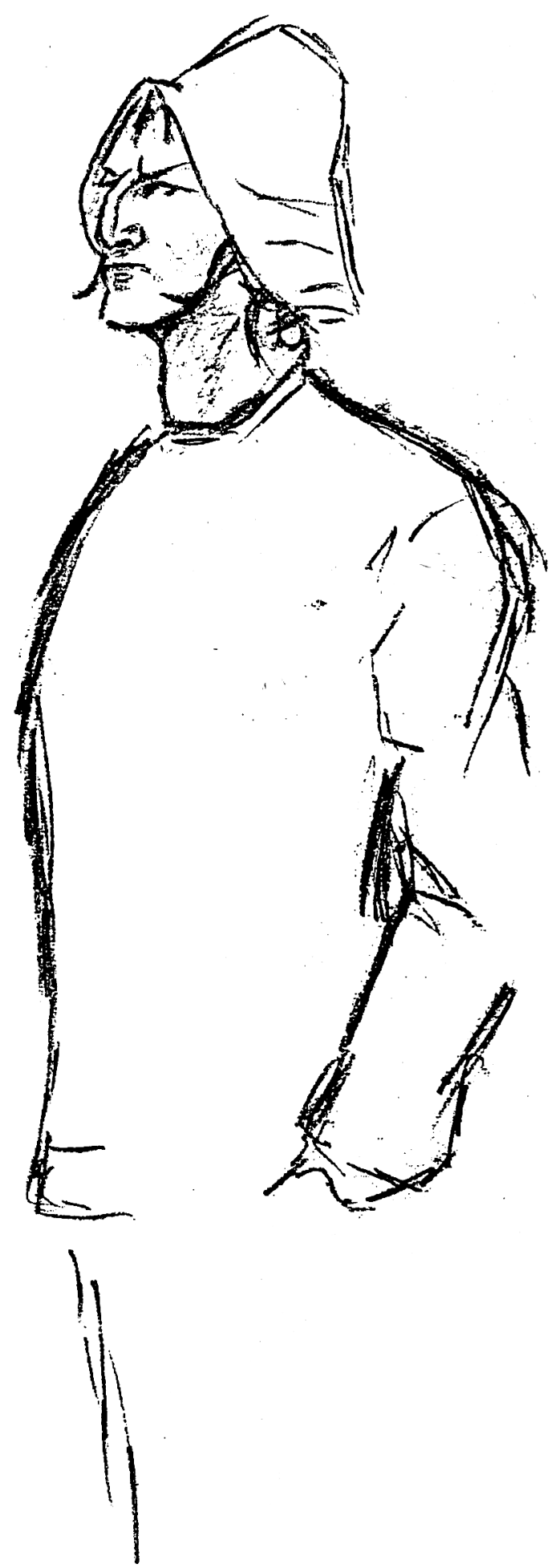


Ferier, dels Sygdom mellem Personalet har hindret os $\mathbf{i}$ at faa Arkivet opstillet saaledes, at det er muligt at faa Overblik over det. " Han bad om "Taalmodighed endnu et Par Maaneder", da ville alt være „rede til en Konference med paafølgende Aflevering." Brevet sluttede med en kort hilsen vedrørende deres fælles bekendte, hvis skæbne overbibliotekaren havde taget sig meget nær.

Kun en måned senere, den 13. oktober 1941, kunne CarlS. Petersen skrive følgende til Teatermuseets leder:

„Vi er nu færdige med den første Gennemgang af Casino-Arkivet og parat til at modtage Dem paa Teatermuseets Vegne. BibliotekarSv. Lunn vil kunne vise Dem, hvor de til eventuel Indlemmelse i Museet liggende Sager er for Haanden".

Afleveringsforretningen blev overstået, den 23. november samme år kunne Robert Neiiendam kvittere for, at han på Teatermuseets vegne havde modtaget „,en Del Arkivalia, bestaaende af Plakater, Programmer og Billeder, hvoraf en Del indrammede".

I det nye år, den 4. februar 1942 sendte inspektør ved Det ny Teater, Elvin Jensen „Resten af det hos Personer og på Det ny Teater beroede Casino-Arkiv", manuskripter som var blevet udlånt af afdøde direktør Einar Linden. Inspektøren vidste ikke tidligere, hvor disse „med Bestemthed befandt sig" og sluttede: „Skulde mere dukke op, skal det øjeblikkeligt blive tilsendt Biblioteket". En liste vedlagt sagsakten opregner ialt 20 forestillinger, deriblandt kassesucces'er og store folkelige forestillingersom Champagnegaloppen, to suffløreksemplarer af Gøngehøvdingen, Tre Musketerer, Charleys Tante, Alle Mand paa Dæk ledsaget af orkester-materiale, foruden Offenbachs mesterlige operette, Pariserliv.

To dage senere udtrykte overbibliotekaren sin taknemmelighed overfor inspektør Elvin Jensen, for "de med Skrivelse af 4. ds. oversendte Sufflør-bøger og Musikalier henhørende til Casino-Arkiv“.Samtidigundlod han dog ikke at gøre opmærksom på, at der endnu manglede „mangfoldige Stykker af begge Kategorier, særlig af Sufflørbøgerne".

Imidlertid hengik nogle år, til efter verdenskrigens ophør, førend man fra bibliotekets side så sig istand til at samle kræfterne om Casinos Arkiv, foranlediget af en skrivelse fra Ernst Carlsen, dateret den 10. januar 1948, hvori han som giver, forespurgte, „om Biblioteket har udarbejdet Fortegnelse over Arkivet" og hvis dette var tilfældet, ville han "gerne have et saadant Eksemplar tilsendt eller Ret til at lade dette afskrive".

Fra bibliotekets side svarede rigsbibliotekar Svend Dahl i skri- 


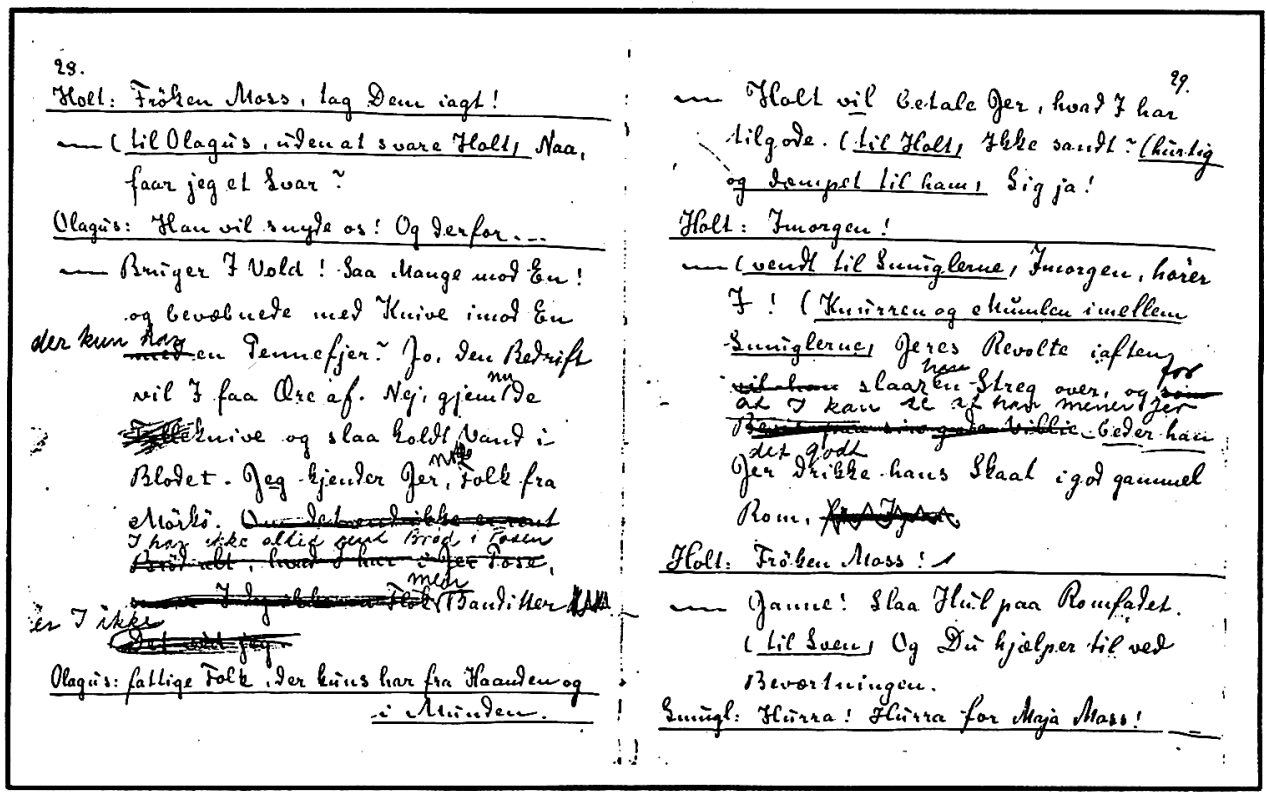

I rollen som "Maja, Moss' Datter" sås i 1890 frk. Clara Bentzen, medens den i 1890 udførtes af henholdsvis fru Olivia Norrie og fru Jenny Keller. På tegningen ses strygninger og tilføjelser gennem tidens løb.

velse af 13. januar, at det endnu ikke havde været muligt, „at afse den fornødne Arbejdskraft til en Nykatalogisering", men istedet kunne han henvise til "den maskinskrevne Fortegnelse, som i sin Tid fulgte med Arkivet"og ved hjælp af denne, „suppleret med enkelte senere tilkomne Sager", kunne "de enkelte Teaterstykker og Rollehefter findes frem".

I foråret fandt biblioteket og Ernst Carisen en løsning på problemerne omkring Casino Arkivs fremtid, idet giver tillod, at arkivet „nu som Depositum" blev overflyttet til Universitetsbibliotekets 1. afdeling og fremover skulle placeres i Dramatisk Bibliotek, „hvor Dagmar-Teatrets Arkiv i Forvejen findes", hvilket fandt sted den 3. maj, samtidig med den fysiske adskillelse af arkivets øvrige dele. I sin skrivelse herom af 25. majtil Ernst Carlsen sluttede Svend Dahl med en indtrængende opfordring, som alene må ses i lyset af bibliotekets også dengang knappe bevillinger, samt onsket om at bringe Casino Arkiv i samme fine tilstand som DagmarTeatrets sufflørbøger. Overbibliotekaren skrev herom:

„Dette sidste er særdeles velkonserveret, hvorimod Casino-Arkivet $\mathrm{i}$ høj Grad trænger til Konservering. I denne Anledning tillader jeg mig at forespørge, om det kunde tænkes, at De vilde kunde fremskaffe et Beløb 
til en saadan Konservering; i saa Fald vilde Bibliotekaren ved Dramatisk Bibliotek sørge for, at Arbejdet bliver udført paa rette Maade. Jeg vilde tro, at et Beløb på Kr. 5000 vilde være tilstrækkeligt, selv med de nuværende høje Indbindingspriser, og det ville være mig en Glæde, hvis det kunne skaffes, saaledes at Casino-Arkivet kunde blive bragt $i$ en smukkere og mere brugbar Stand end nu."

Dette ønske kunne og ville Ernst Carlsen ikke efterkomme, men derimod fandt han, at biblioteket - gavens lempelige vilkår taget i betragtning - burde have draget omsorg for udarbejdelsen af en registrant over arkivet. Eftersom en sådan endnu ikke forelå 7 år efter afleveringen, må givernes svar af 27. maj ses i lyset heraf, da han med på tre linier meddelte Svend Dahl, at han ikke så sig „, i Stand til at yde Bidrag til den ønskede Ordning af Casino-Arkivet.

En egentlig dyberegående registrering af arkivet fra Det kongelige Biblioteks eller Dramatisk Biblioteks side blev aldrig foretaget, idet "den grønne protokol", folianten med titlen Casinos Arkiv. Fortegnelse over Sufflørog Rollebøger, samt en tilsvarende benævnt Register til Rolle-hæfter, fandtes tilstrækkelig anvendelig i forbindelse med den praktiske benyttelse af det omfattende tekstmateriale. På protokollens første side anføres „revideret April 1932". Begge protokoller har været kendt - og formentlig benyttet siden deres aflevering.

Endvidere findes bevaret en registrant, benævit Register over Det gl. Arkiv og Billeder, med et tilhørende notat, en mangelliste, dateret den 6. juli 1949, udarbejdet af Mogens With. Hvorvidt Mogens With har haft med den egentlige ajourføring af "den grønne protokol“ vides ikke.

Sufflørbøgerne blev siden registreret på kartotekskort, såvel under titel, som under forfatter, efter gængse biblioteksprincipper og findes idag registreret på edb - i Det kongelige Biblioteks REX-katalog, base 62, mens ca. 1.000 pakker, tilsyneladende bestående af rollehefter til de enkelte forestillinger, fortsat forblev omhyggeligt indpakket med papiromslag, forsynet med snore og nummereret, således som de formentlig var blevet afleveret til Dramatisk Bibliotek i 1948. De mange pakker lå hengemt og glemt i forskellige depoter, ubeskadiget, trods adskillige flytninger.

Rollehefterne har omsider fundet deres blivende plads, idet disse, sammen med sufflørbøger og de tilhørende protokoller i $1990 \mathrm{blev}$ flyttet til Slotsholmen, $\mathrm{i}$ forbindelse med Dramatisk Biblioteks overførsel til Det kongelige Bibliotek.

I foråret og sommeren 1991 blev rollehefterne gjort til genstand for 
en undersøgelse, herunder indkapsling, dersikrer det uvurderlige materiales fortsatte eksistens. Ialt drejer det sig om 35 hyldemeter, fordelt på ca. 1.000 numre, opstillet i fortløbende nummerorden.

Samtidig hermed blev foretaget en omfattende revison af de oplysninger, som "den grønne protokol" giver om rollehefterne. I protokollens venstre side anføres sufflørbogens titel og et løbenummer, i højre tilsvarende for rollehefterne, nøje afmærket med et kryds. Endvidere er protokollen gennem tiden blevet forsynet med ekstra løbenumre og ført àjour.

Protokollen er, som de to øvrige, blevet dubleret og findes nu tillige i en fotokopi-udgave, hvor et rødt mærke til venstre for rollehefternes titler markerer deres eksistens, foruden tilføjelser. Flere titler, fortrinsvis anført på de sidste fire løse ark, som findes bagest i „den grønne protokol", er slettet, idet disse forekommer i den alfabetiske liste.

Flere af rollehefter oplyser om, hvilke skuespillere der optrådte i de givne roller gennem flere opsætninger, og hefterne gikså at sige i arv. For en stor dels vedkommende er hefterne håndskrevne, autograferede af samtidens skrivere, hovedsageligt tkvinder, der ernærede sig som afskrivere for en beskeden løn, ofte ansatte af teaterbureauer, og hos "Teater August Rasmussen" i København. Materialet er lejlighedsvis blevet lejet ud eller udlånt fra Casino til andre teatre, men lån, leje eller indkøb den anden vej også forekommer.

I det enkelte rollehefte kan skuespillerens egne notater forekomme med strygninger, tilføjelser og andre rettelser, foretaget under eller umiddelbart efter en forestillings prøveforløb. Lejlighedsvis forekommer tegninger af arrangement og kostumer, men hovedparten af de illustrationer, som måtte forekomme i rollehefter hidrører fra de pauser og afbrydelser, den enkelte skuespiller var udsat for. I ventetiden har skuespilleren forsynet heftet med tegninger og vignetter, der ikke blot bærer tidsfordrivets præg, men i flere tilfælde vidner om enkelte skuespilleres kunstneriske talenter på andre områder.

I flere tilfælde mangler sufflørbog, medens rollehefterne fortsat er bevaret. Det er derfor af overordentlig stor betydning, at de manglende sufflørbøger for flere tilfældes vedkommende kan omend ikke erstatte, så næsten rekonstruere den benyttede tekst, fra en tid, hvor hver medvirkende alene havde sin egen rolle udskrevet, eventuelt med partnerens replikker eller stikord indføjet.

Det kan konstateres, at i nogle tilfælde kan manglendesufflørbøger 


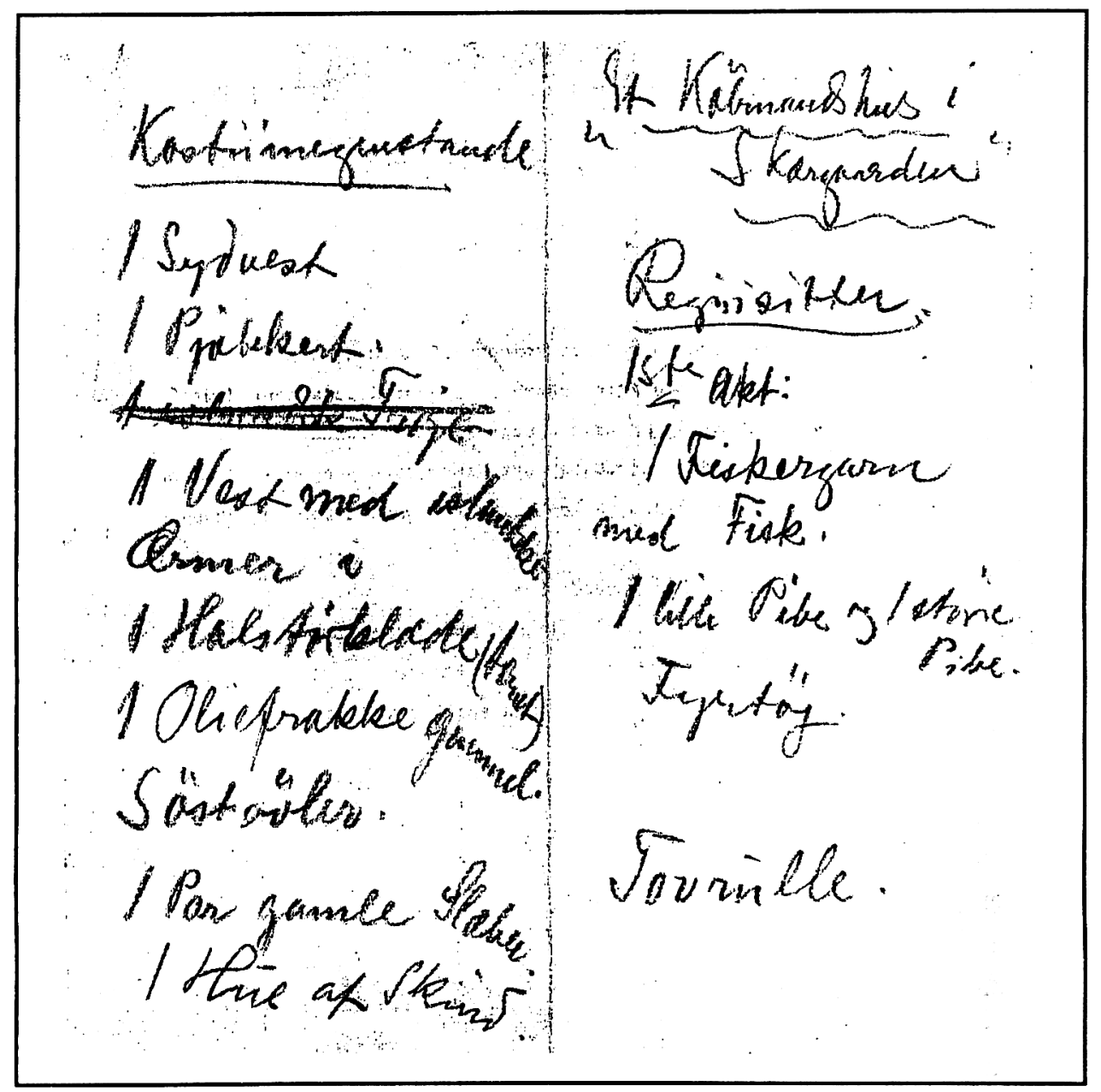

Hr. Bugge og Hr. Holger Madsen spillede rollen som "Peter Gedda, Fisker" i henholdsvis 1890 og 1911. På bagsiden af en stencileret skrivelse, hvori Holger Madsen tilbød sig for den "kommende Saison" ved "eventuelle Aftenunderholdninger" findesen håndskrevet liste over "Kostumegenstande" og Requisitter".

findes iblandt rollehefterne, under det enkelte løbenummer. Dette fremgår af „den grønne protokol", i de tilfælde, hvor ingen titel anføres under sufflørbøger, men alene under "Roller".

Den seneste gennemgang har gjort det klart, hvor uvurderligt rollehefterne og det dertil hørende materiale må betragtes, ikke blot som et enestående supplememt til Casino's øvrige sufflørbøger, men tillige som et selvstændigt stykke dansk teater og -kulturhistorie, der belyser skuespillerens kunst.

32 